THE FORCES OF LAW:

DUTY, COERCION, AND POWER

\title{
LESLIE GREEN
}

\section{Law and things we do not want to do}

At the beginning of his illuminating and challenging work, The Force of Law, Frederick Schauer writes, 'Law makes us do things we do not want to do. It has other functions as well, but perhaps the most visible aspect of law is its frequent insistence that we act in accordance with its wishes, our own personal interests or best judgment notwithstanding. ${ }^{1}$

There are two interesting claims in that opening. The first, which is the centre of gravity of the book, is that law makes us do things we would not otherwise want to do. The second claim is independent of the first, or so it seems to me. It is that law insists that we act in accordance with its wishes, irrespective of our own interests or judgment about the matter. Schauer treats those two claims as nearly interchangeable, or at any rate he interprets the second in light of the first. Characteristically if not necessarily, law makes us do

Professor of the Philosophy of Law, University of Oxford, and Fellow of Balliol College. Professor of Law and Distinguished University Fellow, Queen's University, Canada.

Thanks to Damiano Canale and Giovanni Tuzet for the workshop at Bocconi University where this paper was first presented; to Andrew Simester and Grégoire Webber for comments on a later version; and especially to Fred Schauer for criticism, and for many years of friendship and discussion.

${ }^{1}$ Frederick Schauer, The Force of Law (Cambridge, Mass: Harvard University Press, 2014) 1. 
things by forcing us, and forcing is how the law goes about insisting. The question then arises: if the law can insist without forcing, why is force of special interest to jurisprudence?

One obvious answer is that it is of moral interest. Forcing people to do things calls for justification of some sort, and resort to coercive force bears a special burden of justification. A less obvious answer was defended by writers like Hobbes, Bentham, Austin, and Kelsen. They say that, even when it appears otherwise, law is a sort of coercive force-commands backed up by threats, or commands to deploy force under certain conditions. On this point, H.L.A. Hart parted company with his positivist forebears. He thought coercive force is very important to law and, as we shall see, also to jurisprudence. But he did not think we can identify law with force or with any organization of force: law is an organization of social rules and its resort to force, though humanly necessary, is not conceptually necessary. Schauer does not disagree with Hart on this point, strictly speaking. But he thinks that we miss a lot of what is important about law if we insist on speaking strictly. Schauer suggests that jurisprudence give up its obsession with finding out what features, if any, are necessary to law and legal systems and think more about what is broadly typical of them. We need less analysis and more accounting. And that is the second fish in Schauer's frying pan: a methodology for jurisprudence, a philosophy of legal philosophy.

Schauer's study of coercion in and by the law contains many new insights as well as welcome reminders of home truths. I focus only on points where there seems to be an interesting disagreement between us. I am not the most criticized writer in this book-that distinction falls to Hart-but I am the first criticized, and identified as one of many who make 'efforts to 
marginalize the place of raw force in explaining what makes law distinctive'. ${ }^{2}$ So I hope there may be wider interest in, or at least sympathy for, the following pleadings in self-defense. By way of preview, my claims are these:

(A) The force of law is not one thing but three: the imposition of duties, the use of coercion, and the exercise of power. Duties are norms, and cannot be explained in terms of either coercion or power. People are coerced by law only when subject to a certain kind of threat. People are subject to power whenever the existence of law exerts significant causal influence over their action or interests.

(B) In analytic jurisprudence of Hart's sort, the role of coercion is more central than Schauer allows. He focuses too much on a few negative claims, and too little on a series of important positive claims about the role of coercion in law.

(C) If jurisprudence needs more attention to contingent, typical, truths about law, then it needs something else too. Before we can know what is typical we need to count. Before we can count we need to know that what counts as what. Counting-as is a matter of identifying necessary and sufficient conditions.

2 Schauer, The Force of Law, 2 


\section{The force of duty}

All legal systems impose duties on people. ${ }^{3}$ That is the primary sense in which law 'insists' that we do certain things, whether we want to or not. A duty is a norm to which its subjects must conform, not one to which they may conform when suits them, benefits them, or when they consider it right to do so.

You may wonder whether it is true that we cannot have law without duties. We all know that even a 'society of angels' would need rules, if only to help them coordinate their altruistic activities. ${ }^{4}$ Angels need standing answers to question like this: ' Should Seraphim give way to Cherubim when their flight paths cross, or vice-versa?' They need to settle this, and not on a one-off basis. A regular priority needs to be assigned on some principle or other, whether hierarchy, direction of approach, or urgency of message. But a rule to settle this, one might argue, is not itself a duty-imposing rule. The way settlement rules work, when they do, is by giving angels a way to get what they want: speed without danger. If there is an effective rule, then the question whether they are to comply with it whether they want to or not does not arise. They want to comply, at least on balance. If most of them did not want to comply with a settlement rule, that rule could not yield a settlement. So

\footnotetext{
${ }^{3}$ I use 'duty' and 'obligation' interchangeably.

${ }^{4}$ As Augustine says in his Exposition of the Psalms (32), the society of angels is a place 'where neither adversary there shall be in battle to be tossed nor sluggard from the earth to be stirred up'. Lon Fuller says it is a place without 'man's selfish, quarrelsome, and disputatious nature.' Lon Fuller The Morality of Law, rev ed (New Haven: Yale University Press, 1969) 55. Both agree that rules will nonetheless be needed to guide conduct. See also Joseph Raz, Practical Reason and Norms (Oxford: Oxford University Press, 1999), 157-161.
} 
perhaps if human nature were angelic, a legal system could consist entirely of rules settling what conduct is appropriate, providing information but adding no rational motivation to what is already in place. Not only would it have no need for coercive sanctions, it seems it would also have no need to insist on anything. There could be law without duties.

Two considerations tell against that conclusion. First, as to the angelic subjects: The fairly-tale assumes away recalcitrance and shows that even without it rules are still needed. But it does not assume away rational conflicts. Angels may reasonably hold different views about what is appropriate in certain circumstances, and a reasonable view is one on which there is a reason, pro tanto, to act. If the circumstances only require coordination, then the fact that there is an effective rule will give a reason outweighing other reasonable views, provided they are commensurable with it. But what if they aren't? If the reasons cannot all be measured on a common scale, we cannot count on the reasons provided by the existence of the rule to outweigh the others. What we will need, then, is a reason not to act for what are, still, valid but competing reasons: a reason to go with the principle of urgency over hierarchy, for example. The appeal of hierarchy is not cancelled when we mandate that things are to be settled favour of urgency; but we do get a reason not to act on it. A reason to do something together with a reason not to act on (valid) reasons to the contrary is a plausible account of what it is to have a duty. ${ }^{5}$

There is also a second place duties turn up in law, and this one is inevitable. Even in a world that is not

\footnotetext{
${ }^{5}$ Joseph Raz, Practical Reason and Norms, 49-84; Leslie Green, 'Law and Obligations,' in J. Coleman and S. Shapiro, eds. Oxford Handbook of Jurisprudence and Legal Philosophy (Oxford University Press, 2002), 514-519.
} 
only angelic but without incommensurability, there will be disputes about the bearing of the rules on particular cases, if only because of the ineliminability of vagueness. Law need not resolve every dispute, but it will need to resolve some of them. To do that, it will need to give someone the power and duty to making rulings about what is to be done. The legal rules themselves could be created informally and unintentionally through the emergence of custom - and the most basic rules in every legal system must be created that way-but, however they are created, there must be someone with a duty to make at least some binding determinations about what the rules require.

It follows that duties are one of the things no legal system fails to impose. And duties have a further importance. Although law will also have other sorts of rules, including rules that confer rights, grant permissions, create powers and so forth, each of these can only be fully understood by its relation to duty-imposing rules. Rights have correlative duties; permissions cancel duties; powers give the capacity to create, waive or modify duties (or rights, or permissions or powers, which in turn can only be understood in relation to duties). It is not that these can all be reduced to (conditional) duties, or that the various terms can be dispensed with in favour of statements about duties. The point is that we do not fully understand them without reference to duties.

There is a further moral to be drawn from the fairy tale. Although duty-imposing rules are necessary even among a society of angels, coercive sanctions are not. Angels need no further motivation to comply with their duties. Things are different among mortals like us. Our law needs a back-up plan that comes into effect when we fail to conform to the demands of duty. Plan A is that we should conform without further direction or motivation, whether we want to or not. Plan B is that we will be 
subjected to coercive sanctions if we do not conform. When Plan B comes into effect, the law is past hoping that we will conform to our duties whether we want to our not. It now deploys arrangements that normally make us want to do so, by making conformity the lesser evil. I say 'normally' because, here, the law must place bets on human motivations. A threat of jail induces most people to comply with the law; but it may induce the homeless to break it. Sanctions are subject to the ordinary economy of threats, costs against benefits. Motivation by threat thus lacks the binding, categorical force that Plan A claims to have. And this shows that when coercive sanctions are present-as they generally are-they do not explain the normative character of legal duties.

Now, all this does not quite show that coercive sanctions are 'not a logical feature of our concept of law', or that 'as long as there could possibly be a coercion free legal system, coercion would no longer be a conceptually necessary property of law.' ${ }^{7}$ It shows that there are conceptually possible legal systems that do not deploy any coercion. That leaves open other possibilities, several of which I mention below. But here is an important one: because the authority of law is comprehensive, there are no legal systems that lack norms capable of imposing sanctions if necessary. ${ }^{8} \quad$ Even the angelic legal system contains all the powers necessary to get a coercive apparatus up and running in short order. It is unusual only in that it does not use its necessary powers in that way. So it is a feature of our concept of law that it is

\footnotetext{
6 Joseph Raz, Practical Reason and Norms, 158.

${ }^{7}$ Schauer, The Force of Law, 93.

8 John Rawls, A Theory of Justice (Harvard University Press 1971) 236; Joseph Raz, Practical Reason and Norms, 150-154; Leslie Green, The Authority of the State, 71-78; Grant Lamond, 'Coercion and the Nature of Law,' (2001) 7 Legal Theory 35.
} 
coercive if necessary, though not necessarily coercive. This is not what Bentham, Austin or Kelsen had in mind when they said that law is, of its nature, a coercive instrument. They meant that law not only necessarily has such powers, but also that it necessarily uses them. It might be conceptually necessary to a kind of normative system that it must include certain powers in order to be a system of that kind. But whether a power is actually used is a question of fact. If all legal systems use their coercion-creating powers to create coercive norms and institutions, the explanation for that must lie in whatever it is about the world that makes this so useful to them.

\section{The Force of Coercion}

Schauer does not deny the soundness of an argument like the one I have set out in Section 2. In fact, he accepts it. ${ }^{9}$ But while he agrees that coercion is not a necessary feature of law, he denies the significance of that fact. Laws and legal systems may not be essentially coercive, but they are typically coercive, and the presence of coercion in various guises in all known legal systems is more salient than its absence in some purely theoretical, made-up, fairy-tale legal system. Schauer has an explanation for why so many legal philosophers get things backwards:

Understanding law as typically coercive is hardly a revelation. But there are reasons why Hart and his followers have downplayed this seemingly obvious feature of law. In particular, it is often claimed that many people obey the law just because it is the law

9 Schauer, The Force of Law, 93-94. 
and not because of what the law can do to them if they disobey. ${ }^{10}$

By invoking a wide range of empirical and anecdotal evidence Schauer goes on to argue that this motivational claim is false. But I did not mention or rely on the belief that 'many people obey the law just because it is the law' anywhere in Section 2, and Schauer concedes that an argument of that sort sound. Why then does he think that belief lies at the root of our alleged errors? I think it is because he misinterprets a remark of Hart's and then fails to notice the many ways Hart gives coercion a central role in his theory.

I begin with the misinterpretation. At page 40 of The Concept of Law, Hart assesses Kelsen's argument that the content of every legal system could be represented as a set of orders, directed at judges, to apply sanctions under certain conditions. On this view, law directly guides only the courts and other officials, by telling them when they ought to impose sanctions on people; law's ordinary subjects are guided indirectly. Offhand, that seems wrong. The formation rules of contract, for example, do not prescribe coercive sanctions. And the prohibition on homicide certainly seems addressed to ordinary subjects, not to judges alone. In one of the most ingenious moves in legal theory, Kelsen shows to handle such objections. Rules that do not order sanctions can be understood as fragments of rules that do: as triggers for them, as restrictions on their scope, on their validity, and so on. And a primary duty not to murder is normatively superfluous in a legal system in which courts have a secondary duty to order sanctions against murderers, and in which the constitutional ground rules that ultimately authorize judicial orders are presupposed as binding. We can thus understand law without the need

10 Schauer, The Force of Law, $\mathrm{x}$. 
for distinct power-conferring rules, and without the need for primary duties of any kind.

Hart offers various objections to this-but none of them show that Kelsen's programme of reconstruction is impossible to realize; they aim to show that it is distorting. Our theories of law, says Hart, ought to represent law as it is for any of those who use it, people outside courts as much as people in them. And 'conditional orders to judges' is not how most people see law, most of the time. He then wonders whether Kelsen could reply to this line of criticism by invoking Holmes's edict that, 'If you want to know the law and nothing else, you must look at it as a bad man, who cares only for the material consequences which such knowledge enables him to predict....'11 Then we arrive at the key passage. Hart replies:

It is sometimes urged in favour of theories like the one under consideration that, by recasting the law in a form of a direction to apply sanctions, an advance in clarity is made, since this form makes plain all that the 'bad man' wants to know about the law. This may be true but it seems an inadequate defence for the theory. Why should not law be equally if not more concerned with the 'puzzled man' or 'ignorant man' who is willing to do what is required, if only he can be told what it is? Or with the 'man who wishes to arrange his affairs ' if only he can be told how to do it. ${ }^{12}$

Now, it is crucial to bear in mind that this is part of Hart's reply to Kelsen. It is not Hart's reply to Holmes. Hart's (main) reply to Holmes is, in fact, the same as Kelsen's reply to Holmes: statements of law are not predictions of

\footnotetext{
${ }^{11}$ Oliver Wendell Holmes, Jr., The Path of the Law, (1897) 10 Harvard Law Review, 457-478, 459.

${ }^{12}$ H.L.A. Hart, The Concept of Law, $3^{\text {rd }}$ ed; eds. P. Bulloch and J. Raz, intro. L. Green (Oxford: Oxford University Press, 2012), 40.
} 
coercion and not predictions of anything else either. They are norms. ${ }^{13}$ Holmes has a (crude) theory of the springs of obedience in the bad man. But Kelsen has no theory of the springs of obedience in anyone, since whatever explains people's obedience to law is an empirical, psychological matter, and is thus excluded from a jurisprudence developed under the constraints of his 'pure theory'. Hart's remark about the 'puzzled man' is therefore not offered as counterexample to Kelsen's theory of why people obey, for Kelsen advances no such theory, and Hart's objection to Holmes's theory of law is not based on an objection to Holmes's theory of motivation. The 'puzzled man' example expresses or presupposes no view about why people conform to the law. Since it has no view, it cannot be accused of having a false view of the matter.

This makes trouble for Schauer's discussion of the example and the theory he builds on it. His argument, in essence, is this:

(1) The puzzled man is one who is disposed to comply with the law without the need for coercion 'just because it is the law'. ${ }^{14}$

(2) In actual legal systems, few people if any are disposed to comply with the law just because it is the law. ${ }^{15}$

(3) In actual legal systems, many laws would not enjoy the compliance they do but for the threat of coercion.

(4) So coercion is central to a theoretical understanding of law, and it is a mistake to 'denigrate', 'deny', or 'ignore' it: 'Relegating the

\footnotetext{
${ }^{13}$ Hans Kelsen, General Theory of Law and the State, trans. A. Wedberg (Cambridge Mass: Harvard University Press, 1946) 166-67; Hart, The Concept of Law, 84.

${ }^{14}$ Schauer, The Force of Law, 42, 46.

${ }^{15}$ Schauer, The Force of Law, 61.
} 
coercive aspect of law to the sidelines of theoretical interest is perverse. And thus, adopting a conception of the philosophy of law that facilitates such relegation is even more so.' ${ }^{16}$

It will now be clear what I want to say about this. Let me take the steps in turn.

\section{(1) The Puzzled Man}

As I just argued, the 'puzzled man' example does not presuppose that most people comply with law 'just because it is the law'. What then is it meant to show? The puzzled man is someone who is willing to do what law requires, provided he knows what that is. The basis for his willingness is left open. He may be willing to conform because he thinks legal requirements are a good indicator of what morality requires, or because he wants to fit in with others. In either case he is still using legal norms to guide his conduct in a way that the bad man is not. Nor is the puzzled man one who typically 'internalizes' the norms he follows. ${ }^{17}$ The puzzled man uses norms as norms, which for Hart means having the attitude towards those norms that he calls 'acceptance'. This is a term of art. To 'accept' a norm is to be disposed, on whatever grounds, to use it as a standard for the guidance and evaluation of conduct. ${ }^{18}$ If one conforms to

\footnotetext{
16 Schauer, The Force of Law, 2, 44, 94, 167.

${ }_{17}$ Pace Schauer, The Force of Law, 35-37, 41-42.

${ }^{18}$ The necessary condition for the acceptance of a rule is this: 'What is necessary is that there should be a critical reflective attitude to certain patterns of behavior as a common standard, and that this should display itself in criticism (including self-criticism), demands for conformity, and in acknowledgements that such criticism and demands are justified, all of which find their characteristic expression in the normative terminology of 'ought ', 'must ', and 'should ', 'right' and 'wrong'.' (Hart, The Concept of Law, 56) As to the psychological motivation of taking that attitude, it could be almost anything: 'calculations of long- term interest; disinterested interest
} 
what a standard requires only because one is forced to performing the conforming behaviour, then one does not accept it. But if one uses the standard or applies it to others because one is forced to, then one still 'accepts' it in the pertinent sense. Thus, judges who apply the law because they are afraid that if they do not they will be impeached, accept that law, provided they use it as a standard to guide and evaluate conduct, demand conformity to that standard, criticize deviations from it, and use normative language in stating it.

(2) The quantum of obedience

Schauer's second proposition is quite correct: most people who conform to the law do not do so because of a general disposition to obey the law as such. Some have a piecemeal disposition to obey laws on certain subject matters, or laws created by certain governments, for example, those they voted for. Many more respond, in ways that Schauer examines, to law-provided incentives of various kinds. But quite a lot of conformity is not of either kind. No one can obey a law of which he is unaware. He can conform to what it requires, but the fact that the conduct is legally required cannot be normatively salient to him if he is unaware of it. Most people are unaware of most laws that apply to them. They conform because they have law-independent reasons for avoiding what are, coincidentally, delicts. Such people conform to law without obeying it. Luckily for them, the law does not generally punish failure to obey unless it is accompanied by failure to conform. The exceptions are

in others; an unreflecting inherited or traditional attitude; or the mere wish to do as others do. There is indeed no reason why those who accept the authority of the system should not examine their conscience and decide that, morally, they ought not to accept it, yet for a variety of reasons continue to do so.' (Hart, The Concept of Law, 203). 
the cases in which repudiation of the law's authority is itself an element of the offence (for example, in contempt of court). The law claims obedience, but it mostly settles for conformity.

(3) The need for coercion

The truth of proposition (3) depends on what we mean by coercion. I will not attempt a precise account of it here. In Section 4, below, I suggest that Schauer's account is too broad. In this Section, I rely on a narrower account. Since Schauer's broad view of coercion includes the narrower one, showing that, even for Hart, (narrow) coercion is central to jurisprudence weakens the motivation for Schauer's theory. We do not need a broader view of coercion to show that coercion is centrally important to law and legal theory.

(4) The centrality of coercion

Schauer insists that coercion is central to a theoretical understanding of law and it is a mistake to 'denigrate' it, think it 'irrelevant', 'relegate it to the sidelines', etc. This is his main thesis.

Even making allowances for polemical overstatement, none of these charges applies to Hart's account (nor, I hope, to mine). For Hart unambiguously holds all of the following positive theses about the role of coercion in law:

(C1) All existing legal systems make extensive use of coercive sanctions. ${ }^{19}$

(C2) The emergence of law is partly explained by the greater efficiency of organized sanctions over diffuse social pressure in maintaining order. ${ }^{20}$

\footnotetext{
${ }^{19}$ Hart, The Concept of Law, 23-24, 197-200.

${ }^{20}$ Hart, The Concept of Law, 94-95, 249-50.
} 
(C3) If a social order is dominated by coercive sanctions, that is prima facie reason for thinking that it is a (rudimentary) form of law. ${ }^{21}$

(C4) Sanctions are 'vital' in all legal systems, because only they give adequate assurance to those who would voluntarily comply that they will not be taken for suckers. ${ }^{22}$

(C5) Effective sanctions are the presupposed background of all true statements about any individual's legal obligations. ${ }^{23}$

Some of these theses may be doubtful, and some may actually over-emphasize the role of coercion in law. ${ }^{24}$ But it cannot be denied that someone who accepts all of them is alert to the typically, and importantly, coercive character of law. What more does Schauer want?

Perhaps his complaint lies not with these five affirmative theses about coercion, but with three negative theses that Hart also defends, two of which we have already encountered:

(C6) In every legal system there are some laws that are not enforced by any coercive sanction.

21 '[W]hen physical sanctions are prominent or usual among the forms of pressure, even though these are neither closely defined nor administered by officials but are left to the community at large, we shall be inclined to classify the rules as a primitive or rudimentary form of law.' (Hart, The Concept of Law, 86)

22 Hart, The Concept of Law, 198

${ }_{23}$ '[U]nless in general sanctions were likely to be exacted from offenders, there would be little or no point in making particular statements about a person's obligations. In this sense, such statements may be said to presuppose belief in the continued normal operation of the system of sanctions.' (Hart, The Concept of Law, 8485).

${ }^{24}$ Are sanctions really the only way adequate assurance could be provided, as (C4) would have it? Why not rewards? 
(C7) If human nature were different, it would be possible to have a legal system without any laws that prescribe coercive sanctions.

(C8) The normal function of sanctions in a legal system is ancillary; law's primary functions are those of guiding and evaluating conduct.

These theses, though compatible with (C1) to (C5), entail that coercion, for all the importance Hart assigns it, cannot play the role it does in the theories of Bentham, Austin or Kelsen.

Here, things get cloudy. Schauer actually agrees with (C6) and (C7). He affirms that 'non-coercive law both can and does exist' ${ }^{25}$ and he acknowledges the soundness (though not the importance) of the argument I sketched in Section 2. Does the whole matter then turn on the single thesis, (C8)? I am not sure what Schauer thinks about that one. Perhaps he assumes that to consider sanctions as ancillary to a primary norm is to regard them as unnecessary or unimportant. Not so. It means that we can 'subtract' the sanction and be left with an intelligible directive, and that the function of coercive back-up is to give support to that directive by making it more effective (support that is, in Hart's view, 'vital': (C4)). What is more, an obligation-imposing norm is for Hart is either partly constituted by, or normally concomitant with, 'serious social pressure' to conform: this is part of what marks it as an obligatory norm. ${ }^{26}$

${ }^{25}$ Schauer, The Force of Law, 15.

${ }^{26}$ Hart, The Concept of Law, 86. I am here describing, not endorsing, Hart's view. I think Hart sees the relation between social pressure and obligation as partly constitutive: Leslie Green, 'The Morality in Law,' in L. Duarte d'Almeida and J. Edwards, and A. Dolcetti, eds, Reading HLA Hart's 'The Concept of Law' (Oxford: Hart Publishing, 2013), 177-207, especially $184 \mathrm{ff}$. My interpretation is criticised in Kevin Toh, 'Erratum to: Four Neglected Prescriptions of Hartian Legal Philosophy,' (2014) 33 Law and Philosophy 689-72. Even if I am 
Now, I think (C1) to (C5) add up to a very significant place for coercion in our understanding of law, at any rate, to a place that cannot be said to deny, ignore or relegate coercion to the sidelines of jurisprudence. It is true that (C6), (C7), and (C8) also mean that the provision of coercion is not essential to law, and that there can be law without coercion. But, as I noted, Schauer accepts that. Apart from the false dispute generated in his discussion of the 'puzzled man' example, the lines of substantive disagreement are therefore difficult to discern. (There remains the methodological disagreement; I return to that in Section 5.)

\section{The Force of Power}

So far, I have been working with the view of coercion that is broadly shared by Bentham, Austin and Kelsen. I have argued that this sort of coercion is more central to Hartian jurisprudence than Schauer allows. But it is a further feature of Schauer's view that legal coercion should be understood more broadly. I now sketch some independent reservations about that claim.

One of the more striking features of this booklength defense of the view that coercion is central to law is how little attention is given to the nature of coercion. Schauer assembles a cornucopia of examples of what are said to be legal, or para-legal, coercion. Punishments and penalties, of course; but sometimes also rewards for compliance, some taxes, and perhaps even the nullification of transactions. The loss of reputation that

wrong on the interpretive point, however, it is clear that if serious social pressure is a normally presupposed concomitant, $\grave{a} l a$ (C5), that still marks a very significant connection between coercion and obligation. 
comes with being a law-breaker can, he claims, be coercive. Also, locks on doors, since they prevent people from doing what they might otherwise want to do-and, for the same reason, speed bumps. At points, Schauer seems to assume that most law-induced changes in people's preferences are coercive. It is not surprising, then, that Schauer thinks coercion looms large in law, and that he is convinced that many laws would not enjoy the level of compliance that they do but for coercive support. Almost any significant incentive that produces compliance with law he counts as coercive.

Schauer is right to be interested in law's range of motivating incentives; he is enormously illuminating on the question why some incentives are chosen over others; and he brings us down to earth by reminding us what a fantasy it would be to imagine law without some kind of ancillary motivation for compliance. But is all ancillary motivation coercive? Not according to Kelsen. ${ }^{27}$ Or to Bentham, Austin, Hart or me. Schauer maps the territory as follows:

[I]f we were looking for a rough distinction among the various terms that have been used up to now in this book, we might say that sanctions are what law imposes in the event of noncompliance with legal mandates; that the application of force- meaning physical force - is among law's available sanctions; that law is coercive to the extent that its sanctions provide motivations for people, because of the law, to do something other than what they would have

27 'As a coercive order, the law is distinguished from other social orders. The decisive criterion is the element of force - that means that the act prescribed by the order as a consequence of socially detrimental facts ought to be executed even against the will of the individual and, if he resists, by physical force.' Hans Kelsen, Pure Theory of Law, trans. M. Knight (Berkeley: University of California Press, 1967), 34. 
done absent the law; and that law can be said to exercise compulsion when its coercive force actually does induce the aforesaid shift in behavior. ${ }^{28}$

Then he adds, disarmingly, 'All of these definitions are stipulative, of course ...' ${ }^{29}$

For reasons I will give in Section 5, this 'of course' is troubling. For the moment, let us consider the distinctions themselves. The fact that a law imposes $S$, and $S$ motivates people to act in ways they would not have acted but for that law, shows no more than the fact that the law is, by dint of $S$, to some degree causally effective in motivation. ${ }^{30}$ But not all causation, not even all law-determined causation, is coercive. The issue is both dialectical and theoretical.

The dialectical point is that when Hart and others deny that law is necessarily coercive they are not denying that the existence of law often provides motivation for people to do things they would not otherwise have done. I have never denied that, and it is hard to see how Hart could deny it while affirming (C1) to (C5).

The theoretical point is that although the ordinary semantic range of 'coercion' is broad enough to cover all sorts of things, including social embarrassment, brick walls, and tempting offers, its use in jurisprudence is shaped by two considerations. First, it is a feature of the normative character of law: law is a guide to action, and those who defend the coercion thesis take the view that law guides by

\footnotetext{
28 Schauer, The Force of Law, 129

29 Schauer, The Force of Law, 129

${ }^{30}$ I say 'to some degree' because the law-provided motivation may not succeed: if it does succeed Schauer counts it as 'compulsion'. And I assume, consistently with various passages in the book, that the 'imposition' of $S$ by law need not itself be a coercive act.
} 
coercive proposals, normally by threats. ${ }^{31}$ Second, coercion is marked by the intention to direct someone's will in a particular way, by a proposal they would not normally welcome, and which will make them significantly worse off if they do not behave that way. We say figuratively that coercion leaves people with 'no choice' or, less figuratively, with 'no reasonable choice', but to comply. This explains why we have moral concerns about deploying coercion, and why we prefer non-coercive means of securing compliance to coercive means where both are equally effective. It also explains the connection between coercion and responsibility: those subject to coercive threats are less blameworthy for what they do than are those who choose freely.

It is only by washing out such distinctions that Schauer can treat so many cases of law-provided incentives as forms of coercion. This unhelpfully merges coercion with the more general phenomenon of social power: the capacity to influence people's action and interests. Now, power is a massively neglected topic in legal philosophy, much more neglected than coercion ever has been. ${ }^{32}$ Attention to it raises a host of new questions: whether the power of law need be intentionally produced, whether

\footnotetext{
${ }^{31}$ And possibly by certain offers that share normative features of coercive threats: Virginia Held, 'Coercion and Coercive Offers,' in JR Pennock, and JW Chapman eds, Nomos XIV: Coercion, (Chicago: Aldine-Atherton, 1972); D Zimmerman, 'Coercive Wage Offers,' (1981) 10 Philosophy and Public Affairs 121-145; Onora O'Neill, 'Which are the Offers You Can't Refuse?' in R. G. Frey and C Morris, eds. Violence, Terrorism, and Justice, (Cambridge University Press, 1991) 170-195.

32 So I argue in Leslie Green, 'General Jurisprudence: a $25^{\text {th }}$ Anniversary Essay,' (2005) 25 Oxford Journal of Legal Studies 565-580, and in the 'Introduction' to H.L.A. Hart, The Concept of Law, $3^{\text {rd }}$ ed, xxvii-xxxiii.
} 
structures as well as agents can have power, whether those with power are always responsible for whether and how they use it, and so on. But not all power is coercive. ${ }^{33}$

There is no doubt that effective legal systems use and deploy many different techniques to influence their subjects. In addition to issuing coercive threats, they educate, propagandize, offer services, intervene in markets, and much more. Many of activities of the military and administrative state, and what is left of the welfare state, are conducted through the instrumentalities of law. Schauer observes that one reason Bentham focused so much on law's power to punish, and so little on the capacity to reward, is that the governments he knew had nothing like the capacity of the modern state to provide benefits. ${ }^{34}$ This shows how the power of law takes new and possibly more insidious forms in our world, but it does not give us a reason to think that benefits are the new coercion.

You can see, now, another reason why I am put down as one of the coercion-minimizers: not only do I endorse (C6) to (C8), I take a narrower view of coercion than Schauer does. He writes:

Leslie Green, for example, claims that a regime of "stark imperatives" that simply "bossed people around" or that employed a "price system" to "[structure] their incentives while leaving them free to act as they pleased" would not even count as a

${ }^{33}$ Nor is all influence power. For a range of views on the question, see M. Foucault, Power/Knowledge: Selected Interviews and Other Writings 1972-77. C. Gordon ed. (New York: Pantheon Books, 1980); Steven Lukes, Power: A Radical View (Blackwell, 1974); Peter Morris Power: A Philosophical Analysis (Manchester University Press, 1987). I comment briefly on the issue in Leslie Green, 'Power,' in E. Craig, ed. The Routledge Encyclopedia of Philosophy (Routledge, 1998), vol.7, 610-613. ${ }^{34}$ Schauer, The Force of Law, 111-112. 
"system of law" at all. Such efforts to marginalize the place of raw force in explaining what makes law distinctive follow on Hart's seemingly sound observation that law often empowers rather than coerces. ${ }^{35}$

I do not think that either stark imperatives or steep prices exemplify 'raw force'. Nor is the existence of legal powers my reason for denying that there could be a legal system that resorted only to stark imperatives or market incentives. My point in the passage quoted is rather that a regime consisting solely of stark imperatives-bare orders such as 'Shut up!' or 'Move over!'-makes no claim to authority: that is why they are 'stark'. ${ }^{36}$ I hold that law necessarily makes such a claim. And a market system does not work via directives of any sort: it leaves people free to do whatever they can afford to do. ('Free' in the thin, non-moralized, and sometimes valueless sense of 'free'; the sense in which the poor are free to send their children to expensive private schools, and also free not to.) I think Schauer actually needs to agree with me here, for the first sentence of his book proclaims, 'Law makes us do things that we do not want to do.' Neither stark imperatives nor steep prices do that. They do not make us to do anything. But, like other systems of power, they can be very influential in shaping human behaviour.

Law's power takes many forms and runs in many channels-Schauer traces interesting and often surprising ones. Still, it is the force of power, and not coercion, that we see operating in this sort of case:

When law creates the very possibility of engaging in an activity, it often supplants a similar and law-

\footnotetext{
${ }^{35}$ Schauer, The Force of Law, 2

${ }^{36}$ I take the term 'stark imperatives' from Matthew Kramer, In Defense of Legal Positivism: Law Without Trimmings (Oxford: Oxford University Press, 1999), 83-89.
} 
independent one. And if the law-independent activity is part of people's normal behavior and background expectations, eliminating this possibility and compelling people to use law's alternative operates as a form of coercion. ${ }^{37}$

Admittedly, where the law really does eliminate options, and then compels people to use its alternative, they may well be forced to do what the law wants. But the sort of examples Schauer gives, for instance, the law of contract 'crowding out' promises or a regime of wills displacing informal testamentary directions, do not fit that description. Here, the law does not eliminate the possibility of making promises or disposing of one's estate by means of informal direction. Nor, in the usual course of events, does law compel people to make contracts or wills.

Consider the case of marriage. It is a familiar worry that, when legal marriage arrives on the scene, informal unions come under competitive pressure, and marriage, being the attractive package deal it is, brings a flattening, homogenizing quality to people's intimate lives as they pile into it. The incentives to marry can be powerful, and their structure and terms are rarely accidental. They are commonly the product of deliberate government policies to encourage certain forms of life and discourage others. This is the foundation for the radical critiques of marriage that we heard as sex-neutral marriage regimes became available. They were said to be a conservative push to get gay people to leave behind the creative existentialism of their lives and settle down to bland normality, just like everyone else. Nonetheless, it bears insisting, because it is simply true, that in the usual marriage regimes no one is forced (by law) to marry, that many of the rewards of marriage can be accessed in other

37 Schauer, The Force of Law, 28. 
ways, and that sex-neutral marriage has not in fact homogenized gay lives or made gay people invisible. Contrast all that with genuinely coercive marriage regimes, for example, those that support forced marriages in which unwilling girls are sold off for a price. Here, it is not only that the law causes people to do things they would not do apart from the law; in this case the law forces girls to do things (or helps men force girls to do things) that they do not want to do at all, or do not want to be forced to do. The conceptual and moral differences between the two cases are of the first importance. Marriage law always is, and expresses, a system of social power, whether a benign one that recognizes and stabilizes valuable relationships, or a malignant one that makes bad relationships durable and undermines valuable ones. But we do not need, and should not use, the concept of coercion to explain how law does that, except where coercion is actually on the cards.

\section{Concepts and Counting}

I come, finally, to the methodological agenda of the book. Schauer concedes that coercion is not a 'conceptually necessary' feature of legal systems: there are possible legal systems that contain no coercive norms at all, and that it is possible for a legal system to be effective without such norms. His aim is not to reject these propositions, but to deny their importance for jurisprudence. They are products of an effort to understand the necessary and sufficient conditions for something being law or a legal system, an activity Schauer regards as a misguided, 'essentialist' obsession with what must be at the expense of a more productive interest in what normally is. Conceptual truths about law, 
if there are any, matter less than contingent, empirical truths about the law we have. Thus, in addition to trying to redress the balance in favour of a coercion thesis, Schauer throws down 'a challenge to a prevalent mode of jurisprudential inquiry:'

For most contemporary practitioners of jurisprudence, the principal or even exclusive task of their enterprise is to identify the essential properties of law, the properties without which it would not be law, and the properties that define law in all possible legal systems in all possible worlds. ${ }^{38}$

It is our monomaniacal devotion to that task that drives the view that, 'if coercion is not essential to the very idea or concept of law... then coercion loses its philosophical or theoretical interest in explaining the nature of law....'39

I think this claim is unfair (which is not so important) and also incorrect (which is important). It is unfair to say that an attempt to understand the necessary properties of law is the 'principal or even exclusive task' of 'most' contemporary legal philosophers. It is unfair even if one brackets all of 'special jurisprudence' - the theory of criminal law, tort, constitutional law and so forth-and considers only general jurisprudence. Other tasks squarely at the centre of contemporary attention, tasks undertaken by most if not all of the writers he criticizes, include these:

- Determining whether there are any moral standards to which law, as law, should conform.

- Determining whether there is a moral obligation to obey or respect the law as such.

- Understanding the benefits and costs of regulating conduct by law.

\footnotetext{
${ }^{38}$ Schauer, The Force of Law, $\mathrm{x}$

39 Schauer, The Force of Law, 3.
} 
Obviously, if one has no idea what law is, one is likely to make a hash of these problems, and to that extent they depend on understanding the nature of law as a social and political institution. Apart from that, however, it is going too far to say that contemporary jurisprudence takes the definitional question as its principal, let alone exclusive, task. It is a minority interest. By far the greatest quantity of writing in jurisprudence is either applied moral philosophy-arguments about what our laws and legal institutions ought to be-or doctrinal advice of the 'What-the-Supreme-Court-Should-HaveSaid' variety. (The latter is sometimes called 'interesting' or 'useful' jurisprudence: though to whom or for what purpose is unclear. The courts mostly ignore it.)

More significant than the unfair diagnosis of monomania is the following error. Schauer holds that if coercion is not part of the concept of law, then coercion loses its philosophical or theoretical interest in jurisprudence. As I showed in Section 3, that does not follow. For one thing, if (C8) is true, then coercion plays a very important role in understanding legal obligations, the sort of role Kelsen is fumbling for when he says that 'a legal order as a whole, and a single legal norm, can no longer be regarded as valid when they cease to be effective. ${ }^{\prime 40}$ If (C8) identifies a presupposition of a key class of legal statements, then that is a matter of enormous interest. For another thing, even if coercion is not a conceptually necessary feature of law, the fact that it is pervasively used is no accident. There are non-trivial explanations for why coercive force is a feature of all historical and all existing legal systems: Schauer reminds us of the familiar ones, and adds more to the list. But I am not sure why he thinks this poses any challenge to the prevalent mode of jurisprudential inquiry. After all, it is

${ }^{40}$ Kelsen, Pure Theory of Law, 212. 
Hart who insists that 'a place must be reserved, besides definitions and ordinary statements of fact, for a third category of statements: those the truth of which is contingent on human beings and the world they live in retaining the salient characteristics which they have. ${ }^{\prime 41}$

Compared to the state of play in 1961, we now have more sophisticated ways of understanding the modalities 'necessary' and 'possible', and new views of the relationship between what is necessary and what is knowable a priori. But along the way we have also tended to lose sight of the 'third category' of statements. So we strain to assimilate them either to empirical generalizations-like the (sound) observation that legal systems generate social hierarchies, and that they disproportionately serve the interests of the powerful-or else to a matter of 'definition'. For many philosophical purposes a tightly disciplined understanding of necessity is critical, and one modeled on the behavior of the ordinary quantifiers 'some' and 'all' has advantages. But in the human sciences, as soon as we start down the dark path of things that hold true in 'all possible worlds' we hear a lot of whistling to keep up courage, since we do not have a secure grasp of which worlds are possible. To the extent that Schauer is on Hart's side here, I am on Schauer's. What is 'humanly necessary' is as important to jurisprudence as what is 'strictly' (conceptually, metaphysically, nomically...) necessary.

Sometimes, however, it seems that Schauer wants to go further. At points he seems skeptical of anyone's ability to work out any necessary and sufficient conditions for anything of interest in law. We see that sort of skepticism in this despair-inducing comment: 'Rather than defining law in terms of the nature of its norms or the nature of its sources, we might instead think

${ }^{41}$ Hart, The Concept of Law, 199-200. 
of law simply as the activity engaged in by courts, lawyers, and the sociologically defined array of institutions that surround them.' ${ }^{42}$ Yes, we might: if something definite were picked out by the phrase 'the activity engaged in by courts etc.', or if there were some reason to tie the definition of law exclusively to the activity of such institutions. Unfortunately, among the familiar 'activities' engaged in by courts, lawyers etc. there is also regular and predictable law-breaking, and outside court a large amount of law-application and lawfollowing. So defining law as 'whatever courts do' would not be a good approach, as we learned from the failure of legal realism to produce any plausible way to identify the law of a given jurisdiction.

In addition to this odd recrudescence of legal realism, there is a deeper source of skepticism here. We see it in this passage: 'the existence of live philosophical disputes ... should caution against too quickly accepting the idea that looking for the nature of the phenomenon of law must be an exercise in searching, even in the central or standard cases, for law's essential properties.' ${ }^{43}$ This thought obtrudes again when, in response to my complaint that some legal theorists seem unable to grasp the difference between things being like law and things counting as law, Schauer writes: 'one of many more charitable readings would say that some theorists simply disagree with Green's view that law "properly so called", to use Austin's term, excludes special purpose norm systems such as those of clubs.... ${ }^{44}$

${ }^{42}$ Schauer, The Force of Law, 121.

${ }^{43}$ Schauer, The Force of Law, 40. I have elided the words, 'and somewhat of an empirical consensus' - a consensus about the springs of compliance.

${ }^{44}$ Schauer, The Force of Law, 223, n 25. Schauer is commenting on the following remark of mine: 'For reasons that are obscure to me, scholars in some areas of legal studies seem to grasp the functions 
I am not sure that it is, in fact, more charitable to my interlocutors to say that they 'simply disagree' with me. There is a difference between refuting a position and merely denying it. But, together with the comment about 'live philosophical disputes', this suggests a certain anxiety. Legal philosophers try to understand what is necessary and sufficient to some feature of law; they assemble examples and arguments; they strive for a deeper understanding of our concepts; they sharpen them in ways that are meant to be useful or illuminating. Then other philosophers disagree! I am unmoved. No philosophical explanation of law (or anything else in the human studies) commands universal assent; live philosophical disputes are precisely what to expect in a subject that is both difficult and disputatious. As I have suggested elsewhere, this is reinforced by the sociology of the 'profession' of jurisprudence. ${ }^{45}$ There is no proposition whatever about law has not been denied by some legal theorist or other: that there are legal rules, that they may conflict, that there are unsettled cases, that judges make law, that there is a difference between law and other social norms - careers have been built around denying, with energy and panache, such banal truths.

Schauer's worries about 'essentialism' and about finding necessary and sufficient conditions for things is, moreover, inconstant. Among the most compelling parts of his argument is its demolition of incorrect accounts of 'obedience' that are casually passed around by social scientists as distinguished as Tom Tyler and Stanley

\footnotetext{
'counts as' and 'is a kind of yet apparently cannot master, 'is quite a bit like', or even 'can fruitfully be compared to'. This produces a lot of bad jurisprudence.' Leslie Green, 'The Morality in Law,' in L. Duarte d'Almeida and J. Edwards, and A. Dolcetti, eds., Reading HLA Hart's 'The Concept of Law', $180 \mathrm{n} 10$.

${ }^{45}$ Leslie Green, 'Law and the Role of a Judge,' Oxford Legal Studies Research Paper No. 47/2014 (http://ssrn.com/abstract=2495953).
} 
Milgram. ${ }^{46}$ Schauer shows why it is wrong to go from the fact that people's conformity to law is not wholly selfinterested to the conclusion that people obey the law as such, or that they think it legitimate. We cannot assume that just because people do what an authority figure tells them, they must be doing it because they accept that figure's authority. I agree. ${ }^{47}$ One will get nowhere with these problems until one distinguishes conforming to a directive and complying with that directive. Getting this right can be tricky, and to do so 'we must engage in careful analysis'. ${ }^{48}$ What we need to develop is an account of 'the very idea of obeying the law qua law'. ${ }^{49}$ Recall that Schauer charges Hart with a mistake on this score, by failing to 'clarify carefully exactly what it is to obey the law just because it is the law'. ${ }^{50}$ Nor is Schauer is about to let Tyler, Milgram or Hart displace a compelling analysis with something as flip as a mere stipulation, any more than he is willing to tolerate Austin's stipulation that rewards cannot count as sanctions: 'these issues cannot be determined by definitional edict'. ${ }^{51}$

Indeed they cannot. But I have no idea what 'careful analysis' or 'clarify[ing] exactly what it is to obey', or 'the very idea' of obedience, amount to if they are not attempts to state necessary and sufficient conditions for an attitude to count as obedience-maybe even the 'essence' of obedience. A bare stipulation gets

${ }^{46}$ Tom R. Tyler, Why People Obey the Law (New Haven: Yale University Press, 1990); Stanley Milgram, Obedience to Authority: An Experimental View (New York: Harper and Row, 1975).

47 And so argue in Leslie Green 'Who Believes in Political Obligation?' in W. Edmundson, ed., The Duty to Obey the Law (Totowa, NJ: Rowman and Littlefield, 1999) 301-17.

${ }^{48}$ Schauer, The Force of Law, 6.

${ }^{49}$ Schauer, The Force of Law, 76.

${ }^{50}$ Schauer, The Force of Law, 96.

${ }^{51}$ Schauer, The Force of Law, 113. 
us nowhere; a conceptual error sets us back. It is possible that obedience will turn out to be an attitude that cannot be fully explained in terms of conditions necessary and sufficient for application of the relevant concepts. We will not know until we try. But even if we succeed, we can predict with confidence that at least one philosopher will disagree with the analysis, and he will see his disagreement as a live one. Moreover, he is unlikely, at least early in the game, to say he 'simply disagrees'. There will be more arguments, fresh examples, counterexamples, and so on. If his 'line' is sufficiently startling, it may attract attention, and some may infer from its attention-grabbing allure that there could be something in it. They may do so even if the line is patent nonsense. This is what philosophy can be like, including legal philosophy.

When Schauer is criticizing inept analyses of 'obedience', I am with him. His acuity on these points will come as no surprise to readers of his own influential analyses of rules and other concepts central to jurisprudence. ${ }^{52}$ His sudden downshift to naïve empiricism is therefore surprising. Unhappy with the idea that coercion proves not be part of the concept of law, at least not by the exacting standards that he himself applies to the concept of obedience, Schauer begins to wonder if legal philosophers even know what a concept is. Maybe the concept of $\mathrm{X}$ is more like a stereotype of an $X$ ? He tells us, 'Cognitive scientists who study concept formation have almost universally concluded that people do not use concepts in the way that the "essential feature" view of concepts supposes. ${ }^{53}$ Have they? If so, the first thing we need to know is whether it is in fact the

\footnotetext{
${ }^{52}$ Frederick Schauer, Playing by the Rules: A Philosophical Examination of Rule-Based Decision Making in Law and Life (Oxford University Press, 1993).

${ }^{53}$ Schauer, The Force of Law, 37.
} 
formation of concepts that these scientists were studying-just as we need to know whether it is in fact obedience that Tyler or Milgram were studying. This will call for 'careful analysis', 'clarifying exactly' what a concept amounts to, and so on. How do these cognitive scientists and social psychologists know that they are studying concepts? Do they mount a second set of experiments or surveys to determine what most people think counts as 'concept formation'? Then a third set to figure out how they attribute thoughts to each other? Followed by a fourth? Or maybe it is all just stipulation, all the way down? Concept-blind empiricism is going nowhere fast. Before anyone starts counting anything we need to know what counts as what. There is no counting without counting-as.

This is not a disciplinary point, as if the philosophers have it right and the social scientists have it wrong. The relevant point is internal to social science itself: a measure of $X$ needs to measure $X$, not something $X$-ish, let alone non- $X$ or not- $X$. The best social science is sensitive to this. But we do not always see the best social science in well-known empirical 'tests' of propositions in general jurisprudence. Famous studies of why people 'obey' the law turn out to be studies of something different; influential investigations of correlates and consequences of the 'rule of law' establish little more than the fact that the investigators have a shaky grasp of the rule of law. ${ }^{54}$

\footnotetext{
${ }^{54}$ For a good assessment of some bad analyses, see Tom Ginsburg, 'Pitfalls of Measuring the Rule of Law' (2011) 3 Hague Journal on the Rule of Law 269.
} 


\section{Conclusion}

We should not neglect the force of law. But the force of law is the sum of three different forces: the imposition of duties, the provision of coercion, and the exercise of power. Coercion is a very important member of the trio, but it is what it is, and not one of the other two things. Coercion typifies social control though law, though how typical and in what respects requires some discriminating and some counting. Before we can count how many ways the law has to coerce us, however, we need to know what counts as coercion. Contemporary jurisprudence, even when it denies that coercion is a necessary feature of law as such, finds coercion related to law in many important ways. We can probably improve on that. The tools needed to do so are at hand. They have been for some time. 